\title{
Texture and Other Quality Attributes in Olives and Leaf Characteristics after Preharvest Calcium Chloride Sprays
}

\author{
Eleni Tsantili' ${ }^{1}$, Miltiadis V. Christopoulos, Constantinos A. Pontikis, \\ and Pantousis Kaltsikes \\ Department of Crop Science, Agricultural University of Athens, Iera Odos 75, \\ 11855 Athens, Greece
}

\section{Chariklia Kallianou}

Department of Natural Resources Development and Agricultural Engineering, Agricultural University of Athens, Iera Odos 75, 11855 Athens, Greece

\section{Michalis Komaitis \\ Department of Food Science and Technology, Agricultural University of Athens, Iera Odos 75, 11855 Athens, Greece}

Additional index words. Olea europea, storage, pectic fractions, $\mathrm{Mg}$ concentration, ripening, photosynthesis, chlorophyll

\begin{abstract}
The effect of three preharvest sprays with water or $58.5 \mathrm{~mm}$ calcium chloride $\left(\mathrm{CaCl}_{2}\right)$ on texture and other quality attributes was investigated in 'Konservolia' olives harvested at the black-ripe stage and measured after 1 and 15 days of storage in air at $10^{\circ} \mathrm{C}$ with $85 \%$ relative humidity. Effects on fruit calcium (Ca) and magnesium (Mg) concentrations during the period of spray applications were also studied. Concentrations of $\mathrm{Ca}, \mathrm{Mg}$, and chlorophyll and photosynthesis rate in leaves were measured on the day of final fruit harvest. No foliar or fruit toxicity was observed. In leaves, Ca sprays increased $\mathrm{Mg}$ but did not affect $\mathrm{Ca}$ and chlorophyll concentration and photosynthesis rate. In fruits, Ca sprays prevented the gradual decrease in Ca concentration that occurred in untreated fruits and maintained $\mathrm{Mg}$ at constant levels during ripening on the tree but did not affect fruit size and oil content as measured 1 day after storage. Ca-treated fruits were firmer with lower soluble pectin (SP) concentration and higher calcium pectate (CaP) than controls in both storage days, whereas the protopectin levels were similar in all fruits. Results showed positive linear correlation between $\mathrm{Ca}$ concentration and either firmness or $\mathrm{CaP}$, whereas that between $\mathrm{Ca}$ and $\mathrm{SP}$ was negative as found in fruits stored for 1 day. Fruit production rates of carbon dioxide and ethylene, $L^{*}$ and chroma $\left(C^{*}\right)$ of peel, and hue angle $\left(h^{\circ}\right)$ of flesh were unaffected either by Ca treatment or storage time. Ca treatment did not affect fruit weight loss, the decreases in peel $h^{\circ}$ and flesh $L^{*}$, but increased flesh $C^{*}$ during storage. The results indicate positive effects of preharvest calcium sprays on olive firmness without any negative effect on fruits or leaves.
\end{abstract}

Texture and color are the main quality attributes of black table olives (De Castro et al., 2007). Mafra et al. (2007) reported that the stage of ripening of olive fruit is determinant for a final product with adequate firm texture because decreases in firmness could be magnified after processing. Among the methods developed to maintain firmness during ripening and storage of fresh fruits were those that aim to increase fruit calcium (Ca) concentration by preharvest foliar and fruit sprays with Ca solutions (Ferguson and Watkins, 1989). Preharvest calcium chloride

Received for publication 2 May 2008. Accepted for publication 27 June 2008

We thank Prof. P. Kyriakopoulou of the Agricultural University of Athens for the use of centrifuge Sorval Ultra Pro 80.

${ }^{1}$ To whom reprint requests should be addressed; e-mail etsantili@aua.gr the same size. Therefore, a better firmness maintenance of these olives would be significant.

\section{Materials and Methods}

Plant material. Self-rooted, 15-year-old olive trees (Olea europaea L. cv. Konservolia, Conservolea, or Amphissis) grown in Lamia (lat. $38^{\circ} 44^{\prime} 7^{\prime \prime} \mathrm{N}$, long. $22^{\circ} 55^{\prime} 4^{\prime \prime} \mathrm{W}$, altitude $7 \mathrm{~m}$ ) were sprayed three times with $58.5 \mathrm{~mm} \mathrm{CaCl}_{2}$ (BDH Chemicals, Poole, UK) or with water (controls) up to the runoff point. The concentration of $58.5 \mathrm{~mm}(0.65 \% \mathrm{w} / \mathrm{v})$ $\mathrm{CaCl}_{2}$ was selected as equal or close to the highest used in other species with no toxic effects (Recasens et al., 2004; Tsantili et al., 2007) and after preliminary testing on 'Konservolia'. The $\mathrm{pH}$ of the solutions was adjusted to 7.0 with $1 \mathrm{M} \mathrm{NaOH}$. Calcium penetration depends mainly on natural peel openings and could vary according to the concentration and type of the surfactant used (Harker and Ferguson, 1991). Because there are no data concerning $\mathrm{Ca}$ sprays on olive trees, no surfactant was added in this work. Four trees were selected randomly for each treatment. Sprays were started $30 \mathrm{~d}$ before the final harvest and repeated at $\approx 10$-d intervals. At the time of the first spray, nearly $55 \%$ of the fruits were at the black-ripe stage, whereas at the second and third sprays, this percentage increased to $\approx 70 \%$ and $80 \%$, respectively. For each treatment concentration ( 0 or $58.5 \mathrm{mM} \mathrm{CaCl}_{2}$ ), before each spray and at the final harvest on 24 Nov. 2004 ( 8 d after the third spray), 30 fruits per tree were collected to determine $\mathrm{Ca}$ and magnesium $(\mathrm{Mg})$ concentrations. A few hours before the final fruit harvest, photosynthesis rate was measured on four single attached, mature leaves per tree. On the same day, $\approx 100$ leaves per tree were selected for chlorophyll determination, $\mathrm{Ca}$ and $\mathrm{Mg}$ concentrations, and $\approx 350$ olives per tree were collected for the rest of the fruit measurements. At this stage, all fruits were at the black-ripe climacteric stage. All fruits and leaves collected were macroscopically free of disorders and diseases. Sampling of fruits and leaves per tree, mixing samples from all four trees per $\mathrm{Ca}$ concentration on each sampling day, and sorting out samples in replicates were all carried out randomly. Fruits for storage were sorted out in groups of 10 , placed in plastic pots, and stored in air at $10{ }^{\circ} \mathrm{C}$ with $85 \%$ relative humidity according to a completely randomized design. All measurements were carried out on four replicates. Fruit size and oil content were measured after 1-d storage. The rest of the measurements on stored fruits were carried out after 1 - and 15-d storage and after temperature equilibration at $20^{\circ} \mathrm{C}$. Carbon dioxide $\left(\mathrm{CO}_{2}\right)$, ethylene $\left(\mathrm{C}_{2} \mathrm{H}_{4}\right)$ production rates, and color were measured on the same replicates, whereas the rest of the measurements were each made on different replicates.

Determination of photosynthesis rate and chlorophyll concentration in leaves. Photosynthesis rate was measured by $\mathrm{CO}_{2}$ 
assimilation using a closed portable infrared gas (IRGA) analyzer (LI-6200; LI-COR, Lincoln, NE). The measurement was conducted between 9:00 AM and 11:00 AM when the air temperature was at 18 to $20^{\circ} \mathrm{C}$, the air $\mathrm{CO}_{2}$ concentration at 370 to $380 \mu \mathrm{L} \cdot \mathrm{L}^{-1}$ and the photosynthetically active radiation at 1800 to $2000 \mu \mathrm{mol} \cdot \mathrm{m}^{-2} \mathrm{~s}^{-1}$. The flow rate was $500 \mu \mathrm{mol} \cdot \mathrm{s}^{-1}$ and the rate of net photosynthesis was expressed in $\mathrm{CO}_{2}$ as $\mu \mathrm{mol} \cdot \mathrm{m}^{-2} \cdot \mathrm{s}^{-1}$. Circular leaf disks of $5 \mathrm{~mm}$ diameter, one per leaf from a total of 14 leaves, were cut and used for chlorophyll extraction with $80 \%$ acetone in water $(\mathrm{v} / \mathrm{v})$. Chlorophyll determination was conducted according to Arnon (1949) using an ultravioletvisible spectrophotometer (He $\lambda$ ios Gamma \& Delta; Spectronic Unicam, Cambridge, UK) at 645 and $663 \mathrm{~nm}$. Total chlorophyll $(\mathrm{a}+\mathrm{b})$ was expressed in $\mathrm{g} \cdot \mathrm{m}^{-2}$ of leaf area.

Determination of calcium and magnesium in leaves and fruits. $\mathrm{Ca}$ and $\mathrm{Mg}$ determinations were made on leaves and fruits previously rinsed with $0.1 \mathrm{M} \mathrm{HCl}$ and then twice with distilled water. Leaves were dried at $70{ }^{\circ} \mathrm{C}$ for $3 \mathrm{~d}$ and fruits at $60{ }^{\circ} \mathrm{C}$ for $7 \mathrm{~d}$. Powdered, dried samples of $0.5 \mathrm{~g}$ each were ashed at $500{ }^{\circ} \mathrm{C}$ for $4 \mathrm{~h}$, digested with $5 \mathrm{~mL}$ of $65 \% \mathrm{HNO}_{3}$, filtered, and finally diluted in double-distilled water (v/v). $\mathrm{Ca}$ and $\mathrm{Mg}$ concentrations were determined by atomic absorption spectroscopy (SpectrAA 300; Varian Tecktron, Mulgrone, Victoria, Australia). Results were expressed in $\mathrm{mg} \cdot \mathrm{g}^{-1}$ of dry weight.

Fruit dimensions, weight loss, firmness, and peel and flesh color. Fruit dimensions were measured using a digital caliper with accuracy of $0.03 \mathrm{~mm}$. Fruit weight and weight loss (WL) during storage were determined using a balance with an accuracy of $0.01 \mathrm{~g}$. Firmness values were recorded on two sides on the equatorial zone at $90^{\circ}$ for each unpeeled fruit using a penetrometer (Chantillon DPP; J. Chatillon and Sons, New York, $\mathrm{NY})$ with a scale of 0 to $1 \mathrm{~kg}( \pm 0.01)$ equipped with a conical probe $(5 \mathrm{~mm}$ diameter $X$ $5 \mathrm{~mm}$ height) at a descending speed of $\approx 50$ $\mathrm{mm} \cdot \mathrm{min}^{-1}$. Data are presented in Newtons (N). Color was measured by a chromatometer (CR-300; Minolta, Ahrensburg, Germany) and was expressed in $\mathrm{L}^{*}$, hue angle $\left(\mathrm{h}^{\circ}\right)$, and chroma $\left(\mathrm{C}^{*}\right)$. Three color measurements were made on each unpeeled fruit, two on opposite sides and one on the fruit top (Tsantili and Pontikis, 2004). Flesh color values were recorded on the other two opposite sides of fruits after peeling.

Fruit respiration and ethylene production rates. Both responses were determined on the same fruits at $20^{\circ} \mathrm{C}$ according to Tsantili and Pontikis (2004). Respiration, as $\mathrm{CO}_{2}$ production, was measured before $\mathrm{C}_{2} \mathrm{H}_{4}$ determination using a closed portable IRGA analyzer (LI-6200; LI-COR) connected to a $750-\mathrm{mL}$ airtight jar. Each sample included 10 fruits and the flow rate was adjusted to 900 $\mu \mathrm{mol} \cdot \mathrm{s}^{-1}$. The $\mathrm{CO}_{2}$ production rates were expressed in $\mu \mathrm{mol} \cdot \mathrm{kg}^{-1} \mathrm{~h}^{-1}$. Ethylene production was measured after $2 \mathrm{~h}$ enclosure in $320-\mathrm{mL}$ sealed jars. Ethylene was analyzed by injection into a $120-\mathrm{cm} \times 0.2-\mathrm{cm}$ i.d. column of 80 to 100 mesh activated alumina (Restek, Bellefonte, PE) in a gas chromatograph (Sigma 300; Perkin-Elmer, Norwalk, CT) equipped with a flame ionization detector. The detection limit was $\approx 10 \mathrm{~nL} \cdot \mathrm{L}^{-1}$ and $\mathrm{C}_{2} \mathrm{H}_{4}$ production rates were expressed in $\mathrm{nmol} \cdot \mathrm{kg}^{-1} \cdot \mathrm{h}^{-1}$.

Fruit oil content. The oil content, as percent of fresh weight, was determined by the Soxhlet method after 1-d storage. Fruits were dried at $60{ }^{\circ} \mathrm{C}$ for $7 \mathrm{~d}$ and then at $105^{\circ} \mathrm{C}$ for $3 \mathrm{~h}$. Three grams of dried sample were extracted with $50 \mathrm{~mL}$ petroleum ether for $6 \mathrm{~h}$.

Fruit pectic fractionation and analysis. Pectic fractionation was carried out according to Gallardo-Guerrero et al. (2002) after some modifications. In particular, the alcohol-insoluble solids (AIS) were extracted by homogenizing $50 \mathrm{~g}$ of destoned olives in an Ultra-Turrax homogenizer ( $T$ 25; Kika Labortechnik, Saufen, Germany) with 60 $\mathrm{mL}$ of $70 \%$ ethanol in water $(\mathrm{v} / \mathrm{v})$ and the homogenate was centrifuged at $3500 g_{n}$ for 5 min. The extraction procedure was repeated three more times in succession followed by two extractions with $60 \mathrm{~mL}$ of acetone. The final residue (AIS) was dried at room temperature under $\mathrm{N}_{2}$. The different pectic fractions were obtained from $200 \mathrm{mg}$ dried AIS. In particular, soluble pectins (SP) were extracted with $20 \mathrm{~mL}$ of distilled water by stirring vigorously in a supersonic bath for $20 \mathrm{~min}$ and centrifuging at 27,000 $\mathrm{g}_{\mathrm{n}}$ (Sorval Ultra Pro 80, New Town, CT) for $15 \mathrm{~min}$. The SP extraction procedure was repeated four times totally. All four supernatants combined were used for SP determination, whereas the final pellet was used for the extraction of EDTA-soluble pectin fraction or calcium pectate $(\mathrm{CaP})$. The $\mathrm{CaP}$ was extracted following the SP procedure, but using $0.1 \mathrm{M}$ buffer Tris- $\mathrm{HCl}$ and $0.2 \%$ EDTA at $\mathrm{pH}$ 6.2. The protopectin (PP) was extracted once from the final pellet after $\mathrm{CaP}$ extraction with $20 \mathrm{~mL}$ of $0.05 \mathrm{~N} \mathrm{NaOH}$. The amount of each pectic fraction was assessed colorimetrically for its galacturonic acid (GA) concentration according to Blumenkrantz and AsboeHansen (1973).

Data analysis. The significance of treatment effects was assessed by applying one-way analysis of variance for all leaf characteristics, fruit dimensions, and fruit weight loss. Split plot analysis was used for the other fruit parameters with $\mathrm{Ca}$ treatment selected as the main plot and the storage days as the subplot apart from fruit $\mathrm{Ca}$ and $\mathrm{Mg}$ concentrations in which the time of sprays was selected as the subplot. Correlation analyses were applied between parameters considered to be linked with fruit texture. To assess the significance of the correlations, the correlation coefficient $r$ was determined from the best fit.

\section{Results and Discussion}

Leaf characteristics. No foliar toxicity was observed during the whole experiment. Calcium treatment increased only $\mathrm{Mg}$ concentrations (Table 1). However, all values found in this work were close to those measured in untreated 'Konservolia' leaves by Loupassaki et al. (2002). Alcaraz-Lopez et al. (2004) found increases in leaf $\mathrm{Ca}$ but small and nonsignificant decreases in $\mathrm{Mg}$ in plum leaves after foliar sprays containing only $\mathrm{Ca}$.

Calcium treatment had no effect on either chlorophyll concentration or on photosynthesis rate (Table 1). Similar values for both attributes have been found in untreated 1year-old leaves of the same cultivar measured in November by Hagidimitriou and Pontikis (2005).

Fruit dimensions, oil content, weight loss, and peel and flesh color. There was no fruit toxicity observed during the whole experiment. Preharvest Ca sprays did not affect fruit weight (9.81 g on average), length and width $(29.92 \mathrm{~mm}$ and $23.76 \mathrm{~mm}$ on average, respectively; $P>0.05$ for the three attributes; data not shown) measured after 1-d storage. On cherries, preharvest Ca sprays at an early stage during fruit development may result in decreased fruit size that was probably the result of cell wall strengthening by $\mathrm{Ca}$ (Facteau et al., 1987).

Oil is a main constituent of olives and its content increases during ripening (Fernandez Diez, 1971). In this work, oil content did not change after $\mathrm{Ca}$ sprays (Table 2) and was close to the highest value for ripe 'Konservolia' (Garrido Fernandez et al., 1997).

During storage, WL was not influenced by Ca treatment and averaged $6.55 \%$ (Table 2). Nanos et al. (2002) reported that WL was 3\% to $5 \%$ for the same cultivar stored at $10{ }^{\circ} \mathrm{C}$ for $25 \mathrm{~d}$, but storage was in humidified air flow.

Calcium treatment, as the main factor, did not affect any of the peel and flesh color parameters. During storage, peel color became darker resulting in a substantial decrease in $\mathrm{h}^{\circ}$, but $\mathrm{L}^{*}$ and $\mathrm{C}^{*}$ values were unaffected (Table

Table 1. $\mathrm{Ca}, \mathrm{Mg}$, chlorophyll concentrations, and $\mathrm{CO}_{2}$ assimilation in leaves of olive trees untreated or treated with preharvest $\mathrm{CaCl}_{2}$ sprays.

\begin{tabular}{lcccc}
\hline & \multicolumn{4}{c}{ Leaf characteristics } \\
\cline { 2 - 5 } $\mathrm{CaCl}_{2}$ & $\begin{array}{c}\mathrm{Ca} \text { concn } \\
\text { treatment }(\mathrm{mg})\end{array}$ & $\begin{array}{c}\mathrm{Mg} \text { concn } \\
\left(\mathrm{mg} \cdot \mathrm{g}^{-1} \mathrm{DW}\right)\end{array}$ & $\begin{array}{c}\text { Chlorophyll } \\
\text { concn }\left(\mathrm{g} \cdot \mathrm{m}^{-2}\right)\end{array}$ & $\begin{array}{c}\mathrm{CO}_{2} \text { assimilation } \\
\left(\mu \mathrm{mol}^{-1} \cdot \mathrm{m}^{-2} \cdot \mathrm{s}^{-1}\right)\end{array}$ \\
\hline 0.0 & 12.17 & 1.75 & 1.21 & 7.61 \\
58.5 & 14.31 & 2.10 & 1.21 & 7.85 \\
$\mathrm{SE}_{\mathrm{Ca}}(\mathrm{n}=4)^{\mathrm{z}}$ & 1.22 & 0.06 & 0.007 & 0.52 \\
$P_{\mathrm{Ca}}{ }^{\mathrm{y}}$ & $\mathrm{NS}$ & $\leq 0.01$ & $\mathrm{NS}$ & $\mathrm{NS}$ \\
\hline
\end{tabular}

${ }^{\mathrm{z}} \mathrm{SE} E_{\mathrm{Ca}(\mathrm{n}=4)}=\mathrm{SE}$ of means.

${ }^{y} P_{\mathrm{Ca}}=$ Probability of the effect of $\mathrm{CaCl}_{2}$ treatment.

$\mathrm{Ca}=$ calcium; $\mathrm{Mg}=$ magnesium; $\mathrm{DW}=$ dry weight; $\mathrm{NS}=$ nonsignificant. 
Table 2. Weight loss, oil content, and peel and flesh color of olive fruit during storage from olive trees untreated or treated with preharvest $\mathrm{CaCl}_{2}$ sprays.

\begin{tabular}{|c|c|c|c|c|c|c|c|c|c|}
\hline \multirow{4}{*}{$\begin{array}{l}\mathrm{CaCl}_{2} \\
\text { treatment } \\
(\mathrm{mM})\end{array}$} & \multirow{4}{*}{$\begin{array}{l}\text { Storage } \\
\text { (d) }\end{array}$} & \multicolumn{8}{|c|}{ Attribute } \\
\hline & & \multicolumn{2}{|c|}{ Whole fruit } & \multicolumn{3}{|c|}{ Peel } & \multirow{2}{*}{\multicolumn{3}{|c|}{$\begin{array}{c}\text { Flesh } \\
\text { Color parameter }\end{array}$}} \\
\hline & & \multirow{2}{*}{$\begin{array}{l}\text { Wt loss } \\
(\%)\end{array}$} & \multirow{2}{*}{$\begin{array}{l}\text { Oil content } \\
(\%)\end{array}$} & \multicolumn{3}{|c|}{ Color parameter } & & & \\
\hline & & & & $\mathrm{L}^{*}$ & $\mathrm{~h}^{\circ}$ & $\mathrm{C}^{*}$ & $\mathrm{~L}^{*}$ & $\mathrm{~h}^{\circ}$ & $\mathrm{C}^{*}$ \\
\hline$\overline{0.0}$ & 1 & - & 23.53 & 30.86 & 65.24 & 22.43 & 64.94 & 346.32 & 4.87 \\
\hline 58.5 & 1 & - & 23.65 & 31.40 & 70.14 & 22.51 & 64.89 & 338.55 & 4.35 \\
\hline 0.0 & 15 & 6.46 & - & 31.10 & 24.60 & 22.59 & 44.00 & 341.91 & 3.80 \\
\hline 58.5 & 15 & 6.64 & - & 30.09 & 29.35 & 21.36 & 46.49 & 345.57 & 5.96 \\
\hline $\mathrm{SE}_{\mathrm{Ca}(\mathrm{n}=4)^{\mathrm{z}}}$ & - & 0.22 & 0.40 & 0.30 & 3.73 & 0.81 & 2.06 & 5.62 & 0.3 \\
\hline $\mathrm{SE}_{\mathrm{D}(\mathrm{n}=4)^{\mathrm{z}}}$ & - & - & - & 0.43 & 5.28 & 1.15 & 2.91 & 7.95 & 0.53 \\
\hline$P_{\mathrm{Ca}}^{\mathrm{y}}$ & - & NS & NS & NS & NS & NS & NS & NS & NS \\
\hline$P_{D^{\mathrm{y}}}$ & - & - & - & NS & $\leq 0.001$ & NS & $\leq 0.001$ & NS & NS \\
\hline$P_{C a} \times D^{\mathrm{y}}$ & - & - & - & NS & NS & NS & NS & NS & $\leq 0.05$ \\
\hline
\end{tabular}

${ }^{\mathrm{z}} \mathrm{SE} \mathrm{Ca}(\mathrm{n}=4)=\mathrm{SE}$ of means for $\mathrm{CaCl}_{2}$ treatment; $\mathrm{SE}_{\mathrm{D}(\mathrm{n}=4)}=\mathrm{SE}$ of means for days in storage.

${ }^{y} P_{C a}=$ probability of the effect of $\mathrm{CaCl}_{2}$ treatment; $P_{D}=$ probability of the effect of storage days; $P_{C a \times D}=$ probability of interaction between $\mathrm{CaCl}_{2}$ treatment and storage days.

$\mathrm{h}^{\circ}=$ hue angle; $\mathrm{C}^{*}=$ chroma; $\mathrm{NS}=$ nonsignificant .

2). Concerning the flesh color, $\mathrm{L}^{*}$ value decreased, whereas $\mathrm{h}^{\circ}$ and $\mathrm{C}^{*}$ were unaffected by storage. However, after 15 -d storage, controls had decreased and Ca-treated fruits had increased flesh $C^{*}$ as compared with 1-d stored fruits, but the effect was not considered negative. Most of the color changes during storage could be possibly ascribed to the ripening process and/or WL as observed in other cases (Tsantili et al., 2007).

Fruit respiration and ethylene production rates. The levels of $\mathrm{CO}_{2}$ and ethylene production rates indicate that fruits were at the climacteric stage (Maxie et al., 1960; Tsantili and Pontikis, 2004) during storage (Table 3). Similar production rates of ethylene and relatively higher of $\mathrm{CO}_{2}$ were found in untreated black-ripe 'Konservolia' olives stored at $20{ }^{\circ} \mathrm{C}$ for $1 \mathrm{~d}$ (Nanos et al., 2002). In this work, Ca sprays had no effect on either $\mathrm{CO}_{2}$ or ethylene production rates during storage. These results disagree with many studies in which $\mathrm{Ca}$ decreased both responses (Recasens et al., 2004) because Ca delays ripening (Poovaiah et al., 1988). However, there were cases in which $\mathrm{Ca}$ did not affect respiration rates (Duque et al., 1999; Tsantili et al., 2007) or both responses (Manganaris et al., 2005). Moreover, the present data, although limited, indicated a $\mathrm{Ca}$ effect on increased firmness rather than a general delay of ripening.

Table 3. Ethylene and $\mathrm{CO}_{2}$ production rates in olive fruit during storage from olive trees untreated or treated with preharvest $\mathrm{CaCl}_{2}$ sprays.

\begin{tabular}{|c|c|c|c|}
\hline \multirow[b]{2}{*}{$\begin{array}{l}\mathrm{CaCl}_{2} \\
\text { treatment (mM) }\end{array}$} & \multirow[b]{2}{*}{ Storage (d) } & \multicolumn{2}{|c|}{ Attribute } \\
\hline & & $\begin{array}{l}\text { Ethylene production } \\
\left(\mathrm{nmol} \cdot \mathrm{kg}^{-1} \cdot \mathrm{h}^{-1}\right)\end{array}$ & $\begin{array}{c}\mathrm{CO}_{2} \text { production } \\
\left(\mu \mathrm{mol} \cdot \mathrm{kg}^{-1} \cdot \mathrm{h}^{-1}\right)\end{array}$ \\
\hline$\overline{0.0}$ & 1 & 20.11 & 1.63 \\
\hline 58.5 & 1 & 17.75 & 1.71 \\
\hline 0.0 & 15 & 20.10 & 1.71 \\
\hline 58.5 & 15 & 19.89 & 1.59 \\
\hline $\mathrm{SE}_{\mathrm{Ca}(\mathrm{n}=4)^{\mathrm{z}}}$ & & 2.48 & 0.21 \\
\hline $\mathrm{SE}_{\mathrm{D}(\mathrm{n}=4)}$ & & 2.97 & 0.29 \\
\hline$P_{C a}{ }^{\mathrm{y}}$ & & NS & NS \\
\hline$P_{D}^{\mathrm{y}}$ & & NS & NS \\
\hline$P_{C a \times D}{ }^{\mathrm{y}}$ & & NS & NS \\
\hline
\end{tabular}

fruit development, whereas that of $\mathrm{Mg}$ may be constant or increase (Ferguson and Watkins, 1992). In this study, there was a gradual decrease in $\mathrm{Ca}$ concentration in untreated fruits during fruit development (Fig. 1A). The levels of $\mathrm{Ca}$ in Ca-treated olives showed a reduction after the first spray but then remained almost constant and higher than controls (Table 4). The difference in $\mathrm{Ca}$ concentration between controls and $\mathrm{Ca}$ treated fruits increased gradually and started to be significant after the second spray. Increased $\mathrm{Ca}$ concentrations in peel and flesh have been observed in peaches (Manganaris et al., 2005) and plums (Alcaraz-Lopez et al., 2004) after preharvest Ca sprays.

In the present study, the initial $\mathrm{Mg}$ concentration in controls was higher than in Ca-treated (Fig. 1B). However, Mg concentration in controls decreased after the first spray and then remained almost stable (Table 4). Ca-treated olives had similar Mg levels during the whole experiment but consistently lower than controls. Correlation analysis between $\mathrm{Ca}$ and $\mathrm{Mg}$ in fruits during $\mathrm{Ca}$ treatment showed no relationship (Table 5). Alcaraz-Lopez et al. (2004) observed that Mg concentration did not change in plums after sprays containing only $\mathrm{Ca}$.
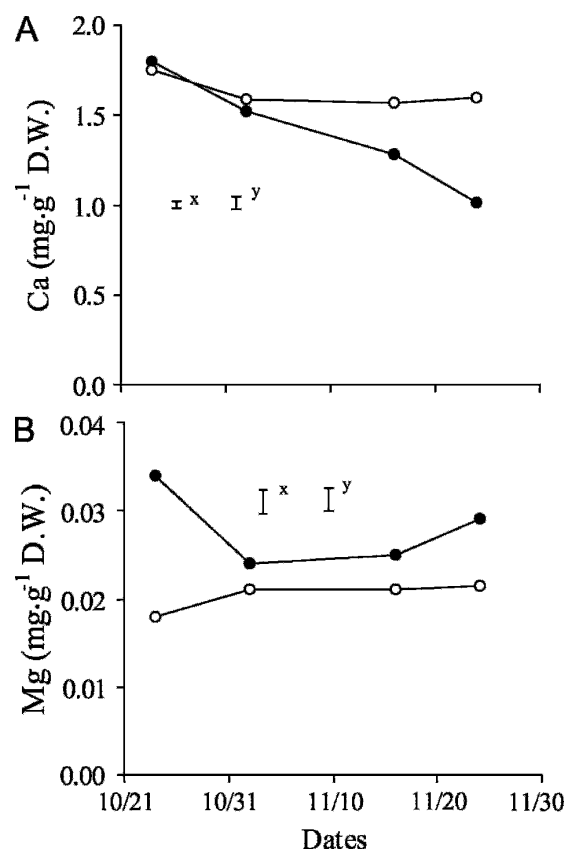

Fig. 1. Calcium (Ca) and magnesium $(\mathrm{Mg})$ concentrations in olive fruits from olive trees untreated or treated with preharvest $\mathrm{CaCl}_{2}$ sprays. Solid points, $0.0 \mathrm{~mm} \mathrm{CaCl}_{2}$; open points, $58.5 \mathrm{~mm} \mathrm{CaCl}_{2}$. (A) Ca concentration; (B) $\mathrm{Mg}$ concentration. Vertical bars are the averaged SES ${ }_{(\mathrm{n}=4)}$; $\mathrm{x}$ bar for concentration of $\mathrm{CaCl}_{2}$ sprays and $\mathrm{y}$ bar for number of sprays.

Firmness and pectic fractions. Calcium treatment was effective on increased firmness in olives from the first measuring day (1-d storage) (Fig. 2A; Table 4). Positive linear correlation with high $r(+0.979)$ was found between fruit $\mathrm{Ca}$ concentration and firmness (Table 5). The present results agree with studies on cherries in that the $\mathrm{Ca}$ effect was observed after 1-d storage (Tsantili et al., 2007), whereas on peaches it was after 15-d storage (Manganaris et al., 2005). In the present work, further changes in firmness during storage were not significant (Table 4) confirming that the positive $\mathrm{Ca}$ effect on increased firmness in olives remained after $15-\mathrm{d}$ storage. The Ca-related firming effect is generally explained by the impact of $\mathrm{Ca}$ on complexion of cell wall and middle lamella polygalacturonate (Morris, 1980). Particularly in olive cell walls, Ferreira et al. (2006) suggested that oligogalacturonides are held by $\mathrm{Ca}$ and pectic polysaccharides occurred as Ca-bridged macrodimers.

Concerning the pectic fractions measured in this work, the concentrations of $\mathrm{SP}, \mathrm{CaP}$, and $\mathrm{PP}$ in controls after 1-d storage were 4.58 $\mathrm{g} \cdot \mathrm{kg}^{-1}$ fresh weight, 1.18 , and 1.16 , respectively (Fig. 2B-D). In 'Gordal' olives, lower values of $\mathrm{SP}$ and $\mathrm{CaP}$ and higher of $\mathrm{PP}$ than in 'Konservolia' were found (Gallardo-Guerrero et al., 2002), but the cultivar was studied at the green stage. Decreases in firmness and losses in uronic acids in cell wall material were observed in 'Hojiblanca' olives during ripening (Jimenez et al., 2001).

All Ca-treated 'Konservolia' olives had reduced $\mathrm{SP}$ concentration and increased $\mathrm{CaP}$ 
Table 4. Probabilities of the effects of number of sprays on olive Ca and Mg concentrations (Fig. 1 data) and of storage days on firmness and pectic fraction concentrations in olives from trees untreated or treated with preharvest $\mathrm{CaCl}_{2}$ sprays (Fig. 2 data).

\begin{tabular}{|c|c|c|c|c|c|c|}
\hline $\begin{array}{l}\text { Probability } \\
(P)\end{array}$ & $\begin{array}{c}\text { Fruit } \\
\mathrm{Ca}\end{array}$ & $\begin{array}{l}\text { Fruit } \\
\mathrm{Mg}\end{array}$ & $\begin{array}{c}\text { Firmness } \\
\text { (F) }\end{array}$ & $\begin{array}{c}\text { Soluble } \\
\text { pectin (SP) }\end{array}$ & $\begin{array}{c}\text { Calcium } \\
\text { pectate }(\mathrm{CaP})\end{array}$ & $\begin{array}{c}\text { Protopectin } \\
\text { (PP) }\end{array}$ \\
\hline$\overline{P_{C a}{ }^{\mathrm{z}}}$ & $\leq 0.001$ & $\leq 0.05$ & $\leq 0.05$ & $\leq 0.001$ & $\leq 0.05$ & NS \\
\hline$P_{S}^{\mathrm{z}}$ & $\leq 0.001$ & $\leq 0.001$ & - & - & - & - \\
\hline$P_{C a \times S}{ }^{z}$ & NS & $\leq 0.001$ & - & - & - & - \\
\hline$P_{D}^{\mathrm{z}}$ & - & - & NS & $\leq 0.001$ & $\leq 0.001$ & NS \\
\hline$P_{C a \times D}{ }^{\mathrm{z}}$ & - & - & NS & $\leq 0.05$ & NS & NS \\
\hline
\end{tabular}

${ }^{\mathrm{z}} P_{C a}=$ probability of the effect of $\mathrm{CaCl}_{2}$ concentration; $P_{S}=$ probability of the effect of number of sprays; $P_{C a \times S}=$ probability of interaction between $\mathrm{CaCl}_{2}$ concentration and number of sprays; $P_{D}=$ probability of the effect of storage days; $P_{C a \times D}=$ probability of interaction between $\mathrm{CaCl}_{2}$ treatment and storage days. $\mathrm{Ca}=$ calcium; $\mathrm{Mg}=$ magnesium; $\mathrm{NS}=$ nonsignificant.

Table 5. Correlation analyses between attributes related to olive texture from olive trees untreated or treated with preharvest $\mathrm{CaCl}_{2}$ sprays.

\begin{tabular}{llcr}
\hline & Correlated attributes & $P^{\mathrm{z}}$ & $r^{\mathrm{z}}$ \\
\hline Fruit $\mathrm{Ca}^{\mathrm{y}}$ & Fruit $\mathrm{Mg}^{\mathrm{y}}$ & $\mathrm{NS}$ & - \\
${\text { Fruit } \mathrm{Ca}^{\mathrm{x}}}$ & Firmness $(\mathrm{FF})^{\mathrm{x}}$ & $\leq 0.001$ & +0.979 \\
Fruit $\mathrm{Ca}^{\mathrm{x}}$ & Soluble pectin $(\mathrm{SP})^{\mathrm{x}}$ & $\leq 0.001$ & -0.958 \\
Fruit $\mathrm{Ca}^{\mathrm{x}}$ & Ca-pectate $(\mathrm{CaP})^{\mathrm{x}}$ & $\leq 0.05$ & +0.916 \\
Fruit $\mathrm{Ca}^{\mathrm{x}}$ & Protopectin $(\mathrm{PP})^{\mathrm{x}}$ & $\mathrm{NS}$ & - \\
Firmness $(\mathrm{F})^{\mathrm{w}}$ & Soluble pectin $(\mathrm{SP})^{\mathrm{w}}$ & $\leq 0.01$ & -0.629 \\
Firmness $(\mathrm{F})^{\mathrm{w}}$ & Ca-pectate $(\mathrm{CaP})^{\mathrm{w}}$ & $\leq 0.001$ & +0.749 \\
Firmness $(\mathrm{F})^{\mathrm{w}}$ & Protopectin $(\mathrm{PP})^{\mathrm{w}}$ & $\mathrm{NS}$ & - \\
\hline
\end{tabular}

${ }^{\mathrm{z}} P=$ probability of correlation between the attributes; $r=$ linear correlation coefficient.

${ }^{\mathrm{y}}$ Data from all harvest days.

'Data after 1-d storage.

${ }^{\text {w}}$ Data after 1-d and 15-d storage.

$\mathrm{Ca}=$ calcium; $\mathrm{Mg}=$ magnesium, $\mathrm{NS}=$ nonsignificant.
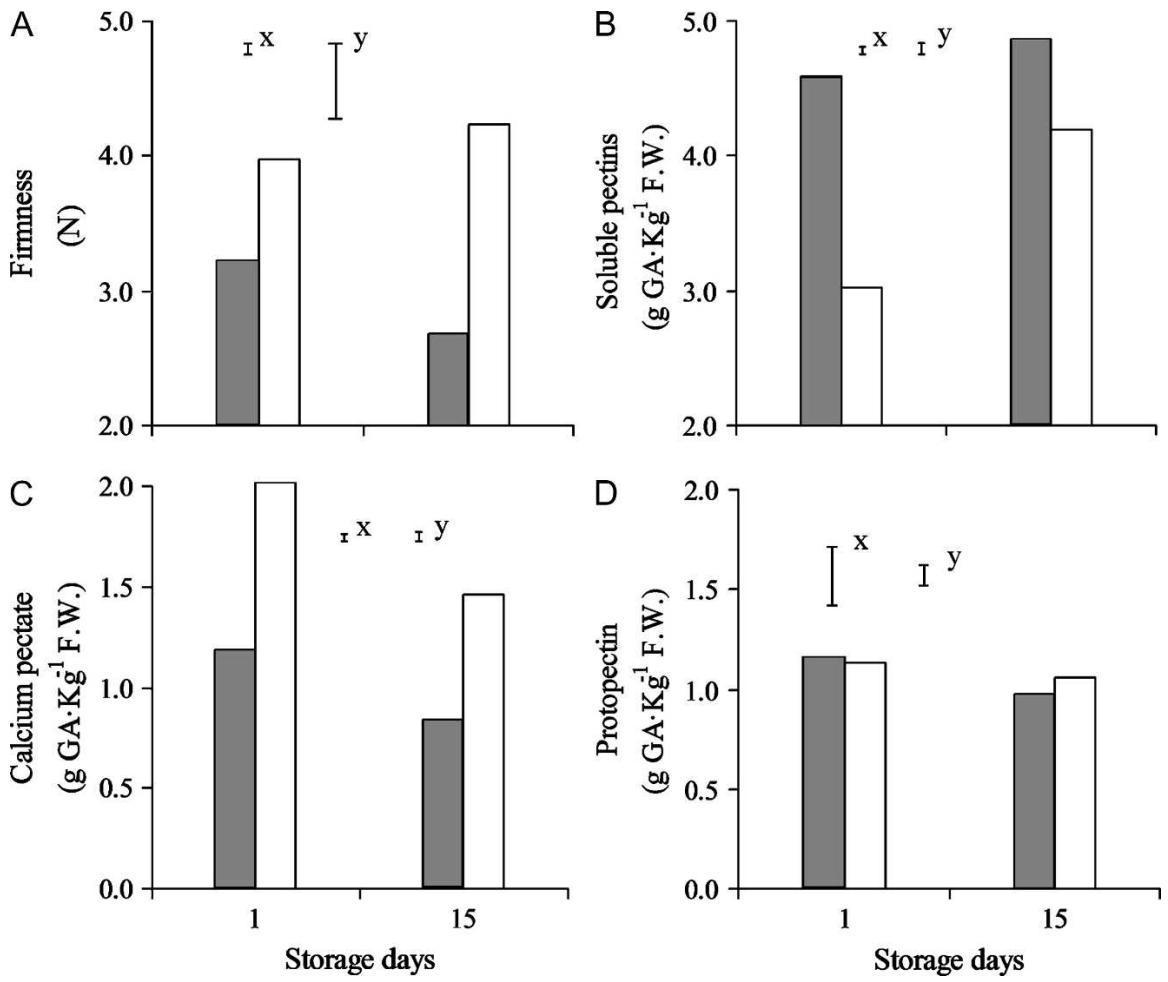

Fig. 2. Firmness and pectic fractions in olive fruits during storage from olive trees untreated or treated with preharvest $\mathrm{CaCl}_{2}$ sprays. Checked columns, $0.0 \mathrm{~mm} \mathrm{CaCl}$; open columns, $58.5 \mathrm{mM} \mathrm{CaCl}_{2} ;(\mathbf{A})$ fruit firmness; (B) soluble pectins; $(\mathbf{C})$ calcium pectate; (D) protopectin. Vertical bars are the averaged SES $(\mathrm{n}=4)$, $\mathrm{x}$ bar for concentration of $\mathrm{CaCl}_{2}$ treatment and $\mathrm{y}$ bar for storage days.

compared with controls, whereas Ca sprays did not affect PP either after 1 -d or 15-d storage (Table 4). Storage time resulted in increases in SP in Ca-treated fruits and decreases in
$\mathrm{CaP}$ in all samples but did not affect the minor changes in PP. Prevention of increases in SP during storage after preharvest $\mathrm{CaCl}_{2}$ sprays has also been found in peaches and cherries (Manganaris et al., 2005; Tsantili et al., 2007).

Furthermore, as far as correlation between fruit $\mathrm{Ca}$ and firmness, correlation analyses between some fruit attributes that were likely to influence fruit texture directly or indirectly showed linear correlations (Table 5). The correlation coefficient $(r)$ between fruit $\mathrm{Ca}$ and $\mathrm{SP}$ was -0.958 and that between $\mathrm{Ca}$ and $\mathrm{CaP}$ was +0.916 , indicating that $\mathrm{Ca}$ prevented pectin solubilization. Firmness was positively correlated with $\mathrm{CaP}(r=+0.749)$ and negatively with SP $(r=-0.629)$, indicating that at least part of the softening is related to pectin solubilization in 'Konservolia'. The increased cell wall-bound $\mathrm{Ca}$ with decreased cell wall degradation has been well demonstrated in Ca-treated apples, suggesting mobility of $\mathrm{Ca}$ to the cell wall (Chardonnet et al., 2003). A decrease in methyl esterification of olive pulp cell wall pectic polysaccharides during ripening (Mafra et al., 2001) could result in increased polymeric GA residues available for complexion with $\mathrm{Ca}$ (Ferreira et al., 2006). This is where $\mathrm{Ca}$ from $\mathrm{Ca}$ treatment could possibly bind to form $\mathrm{Ca}$ bridges and delay olive softening in the present work.

\section{Conclusions}

Three preharvest sprays with $58.5 \mathrm{~mm}$ $\mathrm{CaCl}_{2}$ each seemed to be beneficial to fruit texture of 'Konservolia' olives harvested at the black-ripe stage without any harmful effect on fruits or leaves as assessed by some physiological parameters and under our particular experimental conditions. The main results were that $\mathrm{Ca}$ treatment prevented the decreases in $\mathrm{Ca}$ concentration and retained $\mathrm{Mg}$ levels in fruits during the spraying period, prevented softening and increases in SP concentration, and retained higher levels of $\mathrm{CaP}$ in fruits during storage. These results were obtained by a simple management tool (foliar and fruit application of $\mathrm{Ca}$ ) that growers could readily adopt.

\section{Literature Cited}

Alcaraz-Lopez, C., M. Botia, C.F. Alcaraz, and F. Riquelme. 2004. Effects of calcium-containing foliar sprays combined with titanium and algae extract on plum fruit quality. J. Plant Nutr. 27:713-729.

Arnon, D.I. 1949. Copper enzymes in isolated chloroplasts. Polyphenoloxidase in Beta vulgaris. Plant Physiol. 24:1-15.

Blumenkrantz, N. and G. Asboe-Hansen. 1973. New method for quantitative determination of uronic acids. Anal. Biochem. 54:484-489.

Chardonnet, C.O., C.S. Charron, C.E. Sams, and W.S. Conway. 2003. Chemical changes in the cortical tissue and cell walls of calciuminfiltrated 'Golden Delicious' apples during storage. Postharvest Biol. Technol. 28:97-111.

De Castro, A., P. Garcia, C. Romero, M. Brenes, and A. Garrido. 2007. Industrial implementation of black-ripe olive storage under acid conditions. J. Food Eng. 80:1206-1212.

Duque, P., M.G. Barreiro, and J.D. Arrabaca. 1999. Respiratory metabolism during cold storage of apple fruit. I. Sucrose metabolism and glycolysis. Physiol. Plant. 107:14-23. 
Facteau, T.J., K.E. Rowe, and N.E. Chestnut. 1987. Response of 'Bing' and 'Lambert' sweet cherry to preharvest calcium chloride applications. HortScience 22:271-273.

Ferguson, I.B. and C.B. Watkins. 1989. Bitter pit in apple fruit. Hort. Rev. (Amer. Soc. Hort. Sci.) 11:289-355.

Ferguson, I.B. and C.B. Watkins. 1992. Crop load affects mineral concentrations and incidence of bitter bit in 'Cox's Orange Pippin' apple fruit. J. Amer. Soc. Hort. Sci. 117:373-376.

Fernandez Diez, M.J. 1971. The olive. p. 255-279. In: Hulme, A.C. (ed.). The biochemistry of fruits and their products. Academic Press Inc., London, UK.

Ferreira, J.A., I. Mafra, M.R. Soares, D.V. Evtuguin, and M.A. Coimbra. 2006. Dimeric calcium complexes of arabin-rich pectic polysaccharides from Olea europaea L. cell walls. Carb. Polym. 65:535-543.

Gallardo-Guerrero, L., D. Hornero-Mendez, and M. Mingez-Mosquera. 2002. Pectins as possible source of the copper involved in the green staining alteration of cv. Gordal table olives. J. Agr. Food Chem. 50:6746-6751.

Garrido Fernandez, A., M.J. Fernadez Diez, and M.R. Adams. 1997. Table olives. Chapman \& Hall, London, UK.

Hagidimitriou, M. and C. Pontikis. 2005. Seasonal changes in $\mathrm{CO}_{2}$ assimilation in leaves of five major Greek olive cultivars. Scientia Hort. 104:11-24.
Harker, F.R. and I.B. Ferguson. 1991. Effects of surfactants on calcium penetration of cuticles isolated from apple fruit. Scientia Hort. 46:225233.

Jimenez, A., R. Rodriguez, I. Fernadez-Caro, R. Guillen, J. Fernadez-Bolanos, and A. Heredia. 2001. Olive fruit cell wall: Degradation of pectic polysaccharides during ripening. J. Agr Food Chem. 49:409-415.

Loupassaki, M.H., K.S. Chartzoulakis, N.B. Digalaki, and I.I. Androulakis. 2002. Effects of salt stress on concentration of nitrogen, phosphorus, potassium, calcium, magnesium, and sodium in leaves, shoots, and roots of six olive cultivars. J. Plant Nutr. 25:24572482.

Mafra, I., A.S. Barros, and M.A. Coimbra. 2007. The combined effects of black oxidizing table olive process and ripening on the cell wall polysaccharides of olive pulp. Carb. Polym. 68:647-657.

Mafra, I., B. Lanza, A. Reis, V. Marsilio, C. Campestre, M. De Angelis, and M.A. Coimbra. 2001. Effect of ripening on texture, microstructure and cell wall polysaccharide composition of olive fruit (Olea europea). Physiol. Plant. 111:439-447.

Manganaris, G.A., M. Vasilakakis, I. Mignani, G. Diamantidis, and K. Tzavella-Klonari. 2005. The effect of preharvest calcium sprays on quality attributes, physicochemical aspects of cell wall components and susceptibility to brown rot of peach fruits. Scientia Hort. 107: 43-50.

Maxie, E.C., P.B. Catling, and H.T. Hartmann. 1960. Respiration and ripening of olive fruits. Proc. Amer. Soc. Hort. Sci. 75:275-291.

Morris, E.R. 1980. Physical probes of polysaccharide conformations and interactions. Food Chem. 6:15-39.

Nanos, G.D., E. Agtsidou, and E.M. Sfakiotakis. 2002. Temperature and propylene on ripening of green and black 'Conservolea' olives. HortScience 37:1079-1081.

Poovaiah, B.W., G.M. Glenn, and A.S.N. Reddy. 1988. Calcium and fruit softening: Physiology and biochemistry. Hort. Rev. (Amer. Soc. Hort. Sci.) 10:107-152

Recasens, I., A. Benavides, J. Puy, and T. Casero. 2004. Pre-harvest calcium treatments in relation with respiration rate and ethylene production of 'Golden Smoothee' apples. J. Sci. Food Agr. 84:765-771.

Tsantili, E. and C. Pontikis. 2004. Response to ethylene and its interactive effects with $\mathrm{N}^{6}$ benzyladenine (BA) in harvested green olives during ripening. Postharvest Biol. Technol. 33:153-162.

Tsantili, E., D. Rouskas, M.V. Christopoulos, V. Stanidis, J. Akrivos, and D. Papanikolaou. 2007. Effects of two pre-harvest calcium treatments on physiological and quality parameters in 'Vogue' cherries during storage. J. Hort. Sci. Biotechnol. 82:657-663. 